\title{
NEONATAL CAMPYLOBACTER COLI HEMORRHAGIC ENTERITIS AND BACTERAEMIA
}

\author{
Fernando Ruiz-Esquide ; Mónica Lafourcade²; Edilia Andrews ${ }^{3}$; Heriberto Fernández ${ }^{4 *}$
}

${ }^{1}$ Unit of Neonatology. Department of Pediatrics and Infantile Surgery, Facultad de Medicina, Universidad de Chile, Campus Occidente, Santiago, Chile. ${ }^{2}$ Unit of Microbiology, Clinical Laboratory, Hospital San Juan de Dios, Santiago, Chile.

${ }^{3}$ Department of Microbiology, Universidad de Concepción, Concepción, Chile.

${ }^{4}$ Institute of Clinical Microbiology, Universidad Austral de Chile, Valdivia, Chile.

Submitted: April 04, 2003; Approved: November 21, 2003

\section{SHORT COMMUNICATION}

\begin{abstract}
A case of neonatal campylobacteriosis with hemorrhagic enteritis and bacteraemia due to Campylobacter coli is presented. The mother, from a rural area, had three febrile self-limited diarrheic episodes during pregnancy. The neonate probably acquired the infection during labor. The newborn's serum showed high levels of specific immunoglobulins which could explain the scarce symptoms in this newborn, despite the delay in establishing the gentamicin therapy.
\end{abstract}

Key words: Campylobacter coli, campylobacteriosis, hemorrhagic enteritis, bacteraemia, newborn.

Campylobacter jejuni subsp. jejuni and C. coli are zoonotic bacteria recognized as the most frequent causes of infectious diarrhea in both developed and developing countries $(2,4)$. The clinical spectrum of intestinal campylobacteriosis varies from a mild diarrhea to a severe enterocolitis, with or without other internal organs being involved (12). Despite their high frequency as an agent of diarrhea, the isolation of Campylobacter from blood is uncommon, and blood culture/stool culture isolation rate is 0.008 (9). Campylobacteriosis of newborns, either transplacental or neonatal, is not a well known clinical entity. A case of neonatal transient bacteraemia with hemorrhagic enteritis due to $C$. coli is reported here.

A male newborn with a gestational age of 39 weeks and a weight of $3,420 \mathrm{~g}$ was delivered by spontaneous labor. The amniotic fluid was clear. Apgar score was 9 at 1 and 5 min. After a normal transition period, the newborn was only on a breast milk diet. Thirty-six hours following delivery there was a sudden change in faeces with the presence of fresh blood and mucous. Good general condition was observed, with no fever or vomiting, but there was a mild abdominal distension. Clinical examination showed no intestinal masses or anal injuries. Suspension of oral feeding, fleboclisis and some laboratory tests were indicated. Standard laboratory tests were normal and meningeal infection was ruled out. No antibiotics were given until the $5^{\text {th }}$ day of admission, when a Gram negative curved rod, with a morphology suggestive of Campylobacter was isolated from both stool and blood culture. Gentamicin, $4.0 \mathrm{mg} / \mathrm{Kg}$. every $24 \mathrm{~h}$ for 7 days was prescribed. During the treatment, the newborn remained in fairly good condition and exhibited a progressive normalization of faeces. Breast feeding was restarted, and the patient was discharged after 12 days. Examination by abdominal $\mathrm{X}$-rays showed a normal distribution of air, an absence of neumatosis or hydroaereal levels. Abdominal echotomography ruled out intestinal invagination. Rectum-sigmoidoscopy revealed a pink mucosa without injuries. Two blood cultures (BactT/Alert medium) as well as stool cultures for classical enteropathogens and Campylobacter sp. were performed. No classical enteropathogenic bacteria were isolated. A Gram negative curved rod was isolated from cultures on Skirrow's medium (10), at $42^{\circ} \mathrm{C}$ under microaerophilic atmosphere. The

*Corresponding author: Institute of Clinical Microbiology, Universidad Austral de Chile. PO Box 567. Valdivia, Chile. Tel.: (+5663) 29-3300. E-mail: hfernand@uach.cl 
isolates were oxidase and catalase positive and presumptively identified as Campylobacter sp. Using the APICampy system and Lior's biotyping method (7) the isolates were classified as Campylobacter coli biotype II. For both strains the results of the identification, biotyping, antibiotic susceptibilities (E-test method), adherence, invasiveness, enterotoxigenicity and cytolethal distending toxin (CDT) (3) were the same (Table 1). Also the agglutination titers obtained challenging the mother's and the patient's sera with the strains were identical and are shown in Table 1. Serum immunoglobulins in the mother and child were determined and gave the following results in $\mathrm{mg} / \mathrm{dL}$ : Mother: $\operatorname{IgG} 1537$; IgA 242; IgM 190. Child: IgG 498; IgA 39; $\operatorname{IgM}$ 72. Determination of specific $\operatorname{IgG}$ and $\operatorname{IgM}$ for Campylobacter in both sera were done using an ELISA technique. The optical density reading for IgG was 1.249 for the mother's serum and 0.236 for the child's serum. The negative control was 0.059 . The readings for IgM were of 2.95 for the mother, 0.111 for the child and 0.07 for the negative control.

These findings led us to search for more epidemiological information. The mother was living the first seven months of the pregnancy in Isla Huapi, a rural area near Valdivia, Chile (39 47' Southern latitude). There were no basic environmental sanitary conditions and there was a high risk of zoonosis. During this period, she had three febrile, self limited diarrheic episodes. The epidemiological data, the microbiological results, the presence of high rates of anti Campylobacter IgG serum antibodies, the fact that the newborn was only breast fed as well as the fact that the mother presented a high titer of

Table 1. Characteristics of the Campylobacter coli strains isolated from the blood and stool cultures of the newborn.

\begin{tabular}{lcc}
\hline CHARACTERISTIC & $\begin{array}{c}\text { STRAIN 1 } \\
\text { (blood culture) }\end{array}$ & $\begin{array}{c}\text { STRAIN 2 } \\
\text { (stool culture) }\end{array}$ \\
\hline SPECIES & C. coli & C. coli \\
BIOTYPE & II & II \\
\hline SUSCEPTIBILITY TO: & & \\
Gentamicin & 0.064 & 0.064 \\
Tetraciclyne & 0.064 & 0.064 \\
Ciprofloxacin & 0.008 & 0.008 \\
Erythromycin & 0.049 & 0.049 \\
Ampicillin & 0.50 & 0.50 \\
Cloramphenicol & 0.38 & 0.38 \\
\hline VIRULENCE FACTORS: & & \\
Adherence & + & + \\
Invasiveness & + & + \\
CDT & + & + \\
Enterotoxigenicity & - & - \\
\hline AGGLUTINATION TITERS: & & \\
with new borns serum & $1: 250$ & $1: 250$ \\
with mothers serum & $1: 250$ & $1: 250$ \\
\hline
\end{tabular}

agglutinins when her serum was challenged with the isolated strains, leads us to concluded that this case corresponds to a mother-to-child transmission. Most of the neonatal campylobacteriosis cases correspond to neonates born to mothers who had Campylobacter diarrhea during the peripartum period $(8,9,11)$. In this case, the bacterium was acquired during labor and this is the first documented description of a motherto-child transmitted C. coli infection in Chile, and probably in South America. Perinatal transmission of Campylobacter has been reported in industrialized nations $(1,11)$. However, in developing countries little is known, despite abortion due to $C$. jejuni have been reported (8).

The main symptom of this patient was a hemorrhagic enteritis, a symptom common in campylobacteriosis in milk fed babies, but not in newborns. In the latter, bacteraemia complicated with meningitis seems to be a common occurrence (1). In this case, the high agglutination titers (1:250) found in the mother's and child's sera corroborate the mother-to-child transmission. This newborn developed an hemorrhagic enteritis and a consequent bacteraemia. This clinical expression as well as the lack of invasion of other parenchyma, despite the relative delay in starting antimicrobial treatment, could be related to the high levels of immunoglobulins which were found. It must be taken into account that the mother had three self limited diarrheic episodes which may have allowed the development of the specific immune condition reported here. The passive transmission of the antibodies may have helped to prevent a wide spread dissemination of the bacteria, which in premature babies and neonates can cause severe damage due to vasculitis at the meningeal level or in other parenchyma $(1,8,11)$. Breast feeding during the whole hospitalization period, may have allowed the newborn to acquire enough specific secretory IgA to minimize the bacteria pathogenic properties, also contributing to limit local hemorrhaging and bacteraemia. We did not have the opportunity to measure colostrum IgA levels, but the serum concentration $(242 \mathrm{mg} / \mathrm{dL}$ ) suggests that there was an active local secretory response. The specific IgM immunoglobulins titers of the newborn give grounds to believe that this was a recently acquired infection and that a great part of the IgG titer reflects a passive transmission. On the other hand, the strains showed both adherence and invasive capacity and CDT production which suggests that these virulence factors could explain the hemorrhagic enteritis and the consequent bacteremia (5).

Following the positive culture results, the child was treated with gentamicin for one week starting from the $5^{\text {th }}$ day of hospitalization. Septicaemia is the predominant criterion for the administration of this antibiotic. Erythromycin should be used only for intestinal infections. Both strains were susceptible to both antimicrobial drugs.

The diagnosis of neonatal campylobacteriosis is difficult and probably underestimated. In addition, with routine microbiological methods the isolation from blood samples is 
quite unusual. In this case, the use of the BactT/Alert system allowed the isolation of $C$. coli, showing that it is effective for the diagnosis of Campylobacter bacteraemia as was previously demonstrated by Schonheyder et al (9).

Finally, we must bear in mind that perinatal infection, one of the manifestations of this zoonosis, must be considered for weakened patients and in all milk fed babies carrying an enteric condition, especially in those coming from rural areas with poor or deficient basic environmental sanitary conditions (12).

\section{ACKNOWLEDGMENTS}

This work received financial support from Grants FONDEDCYT 1980920 and 1030245 and Grant DID-UACH 2001S-33.

\section{RESUMO}

\section{Enterite hemorrágica e bacteremia neonatal produzida por Campylobacter coli}

Um caso de campylobacteriose neonatal com enterite hemorrágica e bacteremia produzido por Campylobacter coli é apresentado. A mãe, proveniente de uma região rural, apresentou durante a gravidez, três episódios de diarréia autolimitada. A infecção no recém nascido provavelmente foi adqüirida durante o parto. Os altos níveis séricos de immunoglobulinas específicas poderiam explicar a escassa sintomatologia, apesar da demorada prescrição do tratamento com gentamicina.

Palavras-Chave: Campylobacter coli, campylobacteriosis, enterite hemorrágica, bacteraemia, recém-nascido.

\section{REFERENCES}

1. Blaser, M.J.; Taylor, D.N.; Feldman, R.A. Epidemiology of Campylobacter jejuni infections. Epidemiol. Rev., 5:157-176, 1983.

2. Fernández, H. Thermotolerant Campylobacter species associated with human diarrhea in Latin America. J. Braz. Ass. Adv. Sci., 44:3943, 1992.

3. Fernández, H.; Eller, G. Oecological distribution and virulence factors of Campylobacter jejuni and C. coli in Southern Chile. Clin. Microbiol. Infect., 6(Suppl.1):229-310, 2000.

4. Friedman, C.R.; Neimann, J.; Wegener, H.C.; Tauxe, R.V. Epidemiology of Campylobacter jejuni infections in the United States and other industrialized nations. In: Nachamkin I.; Blaser MJ. (Eds.) Campylobacter $2^{\text {nd }}$ Edition. ASM Press, Washington, DC, 2000, pp.121-138.

5. Kopecco, D.J.; Hu, L.; Zaal, K.J.M. Campylobacter jejunimicrotubule-dependant invasion. Trends Microbiol., 9:389-396, 2001.

6. Lastovica, A.J.; Skirrow, M.B. Clinical significance of Campylobacter and related species other than Campylobacter jejuni and C. coli. In: Nachamkin I.; Blaser MJ. (Eds.) Campylobacter $2^{\text {nd }}$ Edition. ASM Press, Washington, DC, 2000, pp.121-38.

7. Lior, H. New extended biotyping scheme for Campylobacter jejuni, Campylobacter coli, and Campylobacter laridis. J. Clin. Microbiol., 20:636-640, 1984.

8. Ovalle, A.; Cona, E.; Lobos, L.; Angel, R.; Leyton, H. Clinical case abortion in the second trimester due to Campylobacter jejuni. Rev. Chil. Obstet. Ginecol., 62:45-47, 1997.

9. Schonheyder, H.C.; Sogaard, D.; Fredericksen, W. A survey of Campylobacter bacteremia in three Danish counties, 1989 to 1994 Scand. J. Infect. Dis., 27:145-149,1995.

10. Skirrow, M.B. Campylobacter enteritis: a "new" disease. Br. Med. J., 2:2-11, 1977.

11. Thorpy, D.E.; Salit, J.E.; Isaac, J. Campylobacter infections in pregnancy. Am. J. Obstet. Gynecol, 140:423-426, 1981.

12. Walker, R.; Caldwell, M.R.; Lee, E.C.; Guerry, P.; Trust, T.J.; RuizPalacios, G.M. Pathophysiology of Campylobacter enteritis. Microbiol. Rev., 50:81-94, 1986. 